\title{
Carbonyl Stress in the Pathogenesis of Diabetic Nephropathy
}

\author{
Daisuke SUZUKI and Toshio MiYATA
}

\begin{abstract}
Diabetic nephropathy is a major chronic complication of diabetes mellitus and an important cause of increased morbidity and mortality in diabetic patients. Although several lines of evidence have suggested that poor glycemic control undoubtedly plays a significant role, the metabolic events responsible for its development are not understood well. Possible mediators of untowards effects of hyperglycemia include the advanced glycation end products (AGEs). AGEs, carboxymethyllysine and pentosidine, whose formation is closely linked to oxidation, accumulate in the characteristic diabetic glomerular lesions, such as the expanded mesangial matrix and nodular lesions, in co-localization with other oxidation-specific protein adducts, such as malondialdehyde-lysine, 4-hydroxynonenal-protein adduct, and acrolein-protein adduct. These five biomarkers are formed under oxidative stress by carbonyl amine chemistry between protein amino group and carbonyl compounds derived from carbohydrates, lipids, and amino acids. This article focuses on new aspects of the pathology of diabetic nephropathy, implicating an increased oxidative stress and carbonyl modification of proteins by autoxidation products of carbohydrates, lipids, and amino acids in diabetic glomerular tissue damage ("carbonyl stress").
\end{abstract}

(Internal Medicine 38: 309-314, 1999)

Key words: advanced glycation end products (AGEs), oxidation, glycoxidation, carbonyl compounds

\section{Introduction}

With rapid development of therapy for diabetes mellitus, the mortality of acute complications of diabetes mellitus has decreased, but the mortality of chronic complications of diabetes mellitus has increased. Diabetic nephropathy is one of the major chronic complications of both type 1 and type 2 diabetes mellitus and also an important cause of increased morbidity and mortality among these patients. Furthermore, the increase in number of patients with chronic renal failure due to diabetic nephropathy is a major social and economic problem in several countries: diabetic nephropathy has been the most common cause leading to end-stage renal disease in both the United States and Japan (more than one-third of the number of patients with newly end-stage renal disease). The elucidation of the molecular pathogenesis of diabetic nephropathy is therefore necessary for the development of effective treatment modalities to prevent onset of diabetic nephropathy or to retard development of diabetic nephropathy. This article reviews recent studies on the pathogenic mechanisms of diabetic nephropathy, especially the increased glomerular matrix protein modification with carbohydrates and lipids, best described as carbonyl stress.

\section{Pathogenesis of Diabetic Nephropathy}

Several pathogenic mechanisms for diabetic glomerular damage have been proposed. Brenner and Anderson (1) demonstrated that glomerular hyperfiltration and/or hyperperfusion is a causal factor in the development of diabetic nephropathy in type 1 diabetes mellitus. It has also been suggested that the etiology of diabetic complications is associated with the activation of the polyol pathway (2), myo-inositol metabolism abnormalities (3), high activity of protein kinase $C(4,5)$, hypercoagulability (6), and hereditary factors (7). We have recently reported that interleukin 6 and transforming growth factor $\beta$ are important factors in the development of diabetic nephropathy $(8,9)$, and several investigators have demonstrated that cytokines and growth factors play an important role in the pathogenesis of diabetic nephropathy (10-12). Furthermore, we showed that alternation in balance between production and degradation of renal extracellular matrix were implicated in the pathogenesis of diabetic nephropathy $(13,14)$. There are thus a variety of mechanisms accounting for the pathology of diabetic nephropathy (summarized in Table 1).

Poor glycemic control undoubtedly plays a significant role as shown by both clinical (15) and pathological studies (16). Possible mediators of untowards effects of hyperglycemia in-

From the Division of Nephrology and Metabolism, Department of Internal Medicine, School of Medicine, Tokai University, Isehara

Reprint requests should be addressed to Daisuke Suzuki, the Division of Nephrology and Metabolism, Department of Internal Medicine, School of Medicine, Tokai University, Bohseidai, Isehara, Kanagawa 259-1193 
Table 1. Pathogenesis of Diabetic Nephropathy

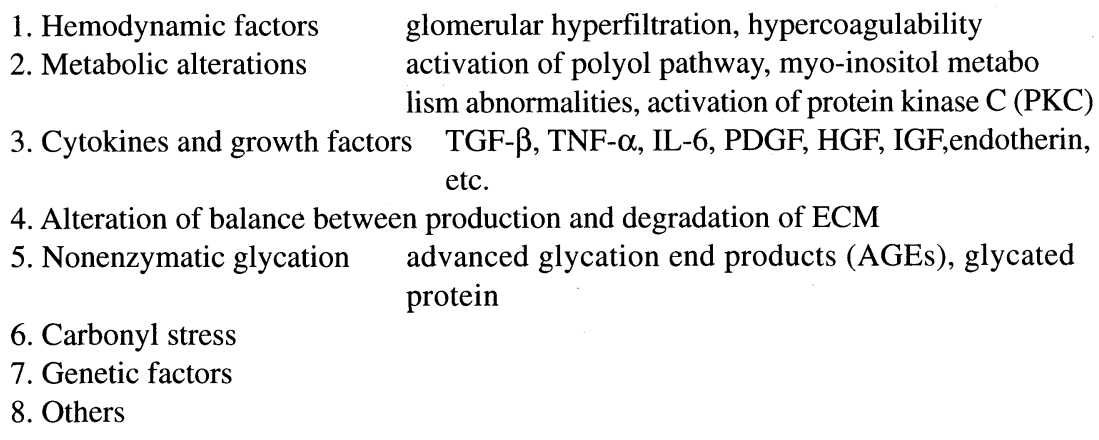

clude the advanced glycation end products (AGEs) known to accumulate in diabetic subjects $(17,18)$. AGEs have thus been proposed as one of important factors in the pathogenesis of diabetic nephropathy (18-20).

\section{Role of AGEs in Diabetic Nephropathy}

AGEs are generated by the Maillard reaction through nonenzymatic glycation and oxidation ("glycoxidation") of protein amino groups (18). AGEs comprise a variety of molecular structures, such as $N^{\varepsilon}$-(carboxymethyl) lysine (CML) (21), pentosidine (22), and pyrraline (23), characterized by different formation mechanisms. AGEs accumulate in plasma and tissue proteins of diabetic patients $(17,24)$. Their accumulation is correlated with the severity of diabetic complications (25, 26). We recently reported that a monoclonal anti-AGE antibody reacts with the mesangial area in patients with diabetic nephropathy, and that the intensity of AGE staining gradually increases in parallel with the degree of mesangial expansion (19). Furthermore, we showed that monoclonal antibody against the reduced glycated lysine reacts with glomerular basement membrane in the glomeruli of patients with diabetic nephropathy (20).

Several lines of evidence suggest that AGEs may be involved in the development of diabetic glomerular lesions $(19,27,28)$. AGEs stimulate matrix production and inhibit mesangial proliferation (29), and the glycated glomerular basement membrane is more resistant to digestion by protease (30). Doi et al (31) showed that mouse mesangial cells exhibit an increase in mRNA and protein synthesis of type IV collagen, laminin and heparan sulfate proteoglycan after exposure to AGEs. Yang et al (32) demonstrated that AGEs induce an increase in mRNA expression for extracellular matrix proteins such as type IV collagen, laminin, and transforming growth factor $\beta$ (TGF- $\beta$ ). On the other hand, an AGE inhibitor, aminoguanidine, reduced these morphological changes (32). More interestingly, AGEmodified proteins stimulate a variety of cellular responses (33$35)$ via a specific cell-surface receptor $(36,37)$ on several cell types including glomerular mesangial cells $(38,39)$.

\section{Carbonyl Stress: Alteration Non-Enzymatic Chemistry in Diabetic Nephropathy}

Under oxidative stress, proteins may be modified either directly by reactive oxygen species with the eventual formation of oxidized amino acids or indirectly by reactive carbonyl compounds formed by autoxidation of carbohydrates, lipids, or amino acids.

Autoxidation of carbohydrates yields reactive carbonyl compounds, precursors of AGEs, such as glyoxal (40), methylglyoxal (41), and glycolaldehyde (42), as well as dehydroascorbate formed by oxidation of ascorbate $(43,44)$. Lipid peroxidation of polyunsaturated fatty acids yields other reactive carbonyl compounds: some are identical to those formed from carbohydrates (45), such as glyoxal and methylglyoxal, and others are characteristic of lipids, such as malondialdehyde (MDA), 4-hydroxynonenal (HNE), and acrolein $(46,47)$. The latter reactive carbonyl compounds produce lipoxidation products, MDA-lysine, HNE-protein adduct, and acrolein-protein adduct, also termed advanced lipoxidation end products. The hydroxy-amino acids, L-serine and L-threonine, are also oxidized and converted to reactive carbonyl compounds, such as glycolaldehyde and acrolein, which are highly reactive with proteins, leading to formation of CML and acrolein-protein adducts (48), respectively. Therefore, products are formed by carbonyl amine chemistry between protein amino group and carbonyl compounds derived from autoxidation of carbohydrates and lipids (40-42, 49, 50).

We recently demonstrated that glycoxidation products, a subclass of AGEs which requires both glycation and oxidation for their formation such as CML and pentosidine, accumulate in expanded mesangial matrix and nodular lesions in diabetic nephropathy, in co-localization with MDA-lysine, a lipoxidation product (27). However, pyrraline, another AGE structure whose deposition is rather independent of oxidative stress, was not found within diabetic glomeruli (27). We therefore hypothesized that the localizations of glycoxidation products and MDA-lysine (both formations are closely related to oxidative process) are independent evidence for local oxidative stress and the increased carbonyl modification of proteins 


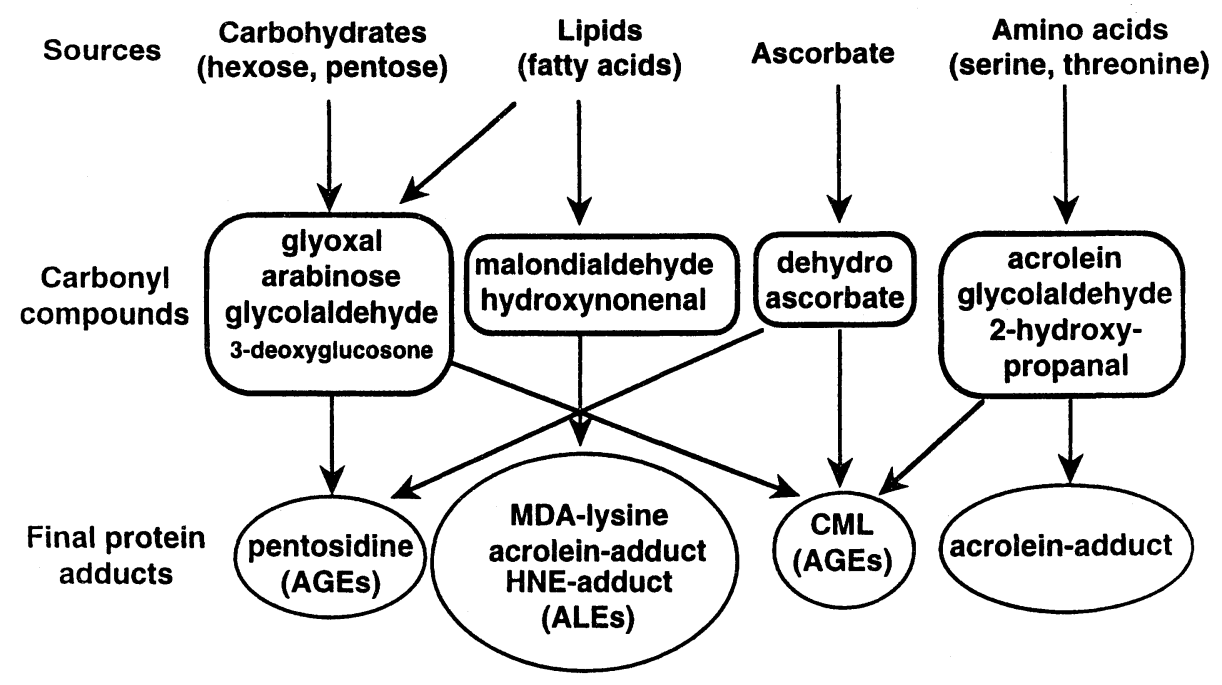

Figure 1. Carbonyl stress pathway.

in diabetic glomerular lesions ("carbonyl stress") (Fig. 1).

\section{Evidence for Carbonyl Stress in Diabetic Glomerular Lesions}

In order to examine the presence of carbonyl stress in diabetic nephropathy, human renal tissues from patients with diabetic nephropathy and control samples were examined, with specific antibodies, to characterize carbonyl modification of proteins by autoxidation products of carbohydrates, lipids, and amino acids: CML (derived from carbohydrates, lipids, and amino acid), pentosidine (derived from carbohydrates), MDAlysine (derived from lipids), HNE-protein adduct (derived from lipids), and acrolein-protein adduct (derived from lipids and amino acid) (51). These antibodies recognize distinct structures and do not cross-react with the other structures, as demonstrated by immunoblot analysis (27).

Open renal biopsy specimens were obtained from 17 noninsulin-dependent diabetes mellitus patients with diabetic nephropathy. Control samples were also obtained from 6 subjects using uninvolved portions of surgically removed kidneys afflicted with malignancies. These subjects had no urinary abnormalities and histological examination of control tissues excluded any glomerular diseases.

The pathological hallmarks of diabetic nephropathy are increased thickness of the glomerular basement membrane and mesangial expansion (52-56). The latter is considered more significant than the former, as expansion of the mesangium has been reported to ultimately lead to renal insufficiency (55). Diabetic patients were thus divided into three grades by the degree of mesangial expansion using light microscopy findings: grade I had mild mesangial expansion, grade II had moderate mesangial expansion, and grade III had severe mesangial expansion with Kimmelstiel-Wilson nodules.

Results of immunohistochemical studies in renal tissues from patients with diabetic nephropathy and control samples are shown in Table 2. The antibodies for CML, pentosidine, MDAlysine, HNE-protein adduct, and acrolein-protein adduct did not stain the glomeruli in normal renal tissues from all 6 control subjects (exemplified for pentosidine and HNE-protein adduct in left and right panels in Fig. 2A, respectively).

In renal tissues of diabetic nephropathy patients, glomeruli were stained positive for CML, pentosidine, MDA-lysine, HNE-protein adduct, and acrolein-protein adduct in patients with diabetic nephropathy (exemplified for pentosidine and HNE-protein adduct in left and right panels in Figs. 2B and $2 \mathrm{C}$, respectively). Immunostaining was mainly observed in the expanded mesangial area and capillary walls. Nodular lesions within the glomeruli were also strongly stained positive for all the 5 biomarkers. The intensity of their immunostaining appeared to increase with the histological severities of diabetic nephropathy.

Table 2. Immunostaining for Glycoxidation and Lipoxidation Products in Normal and Diabetic Renal Tissues

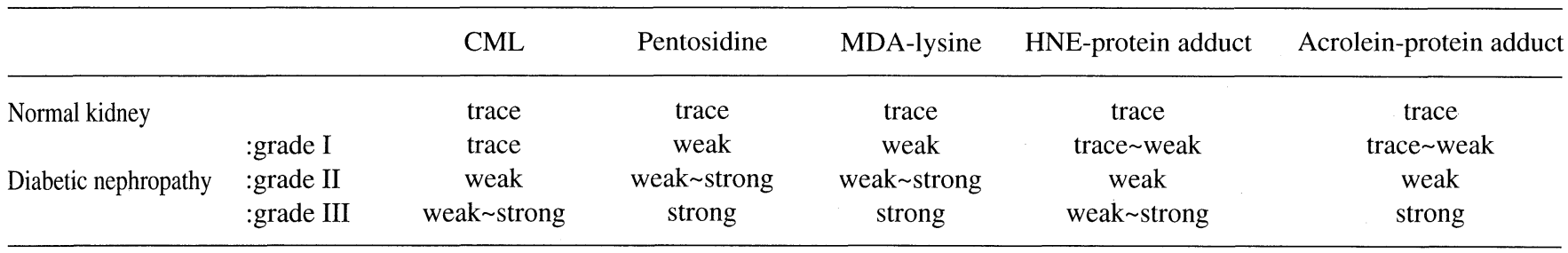




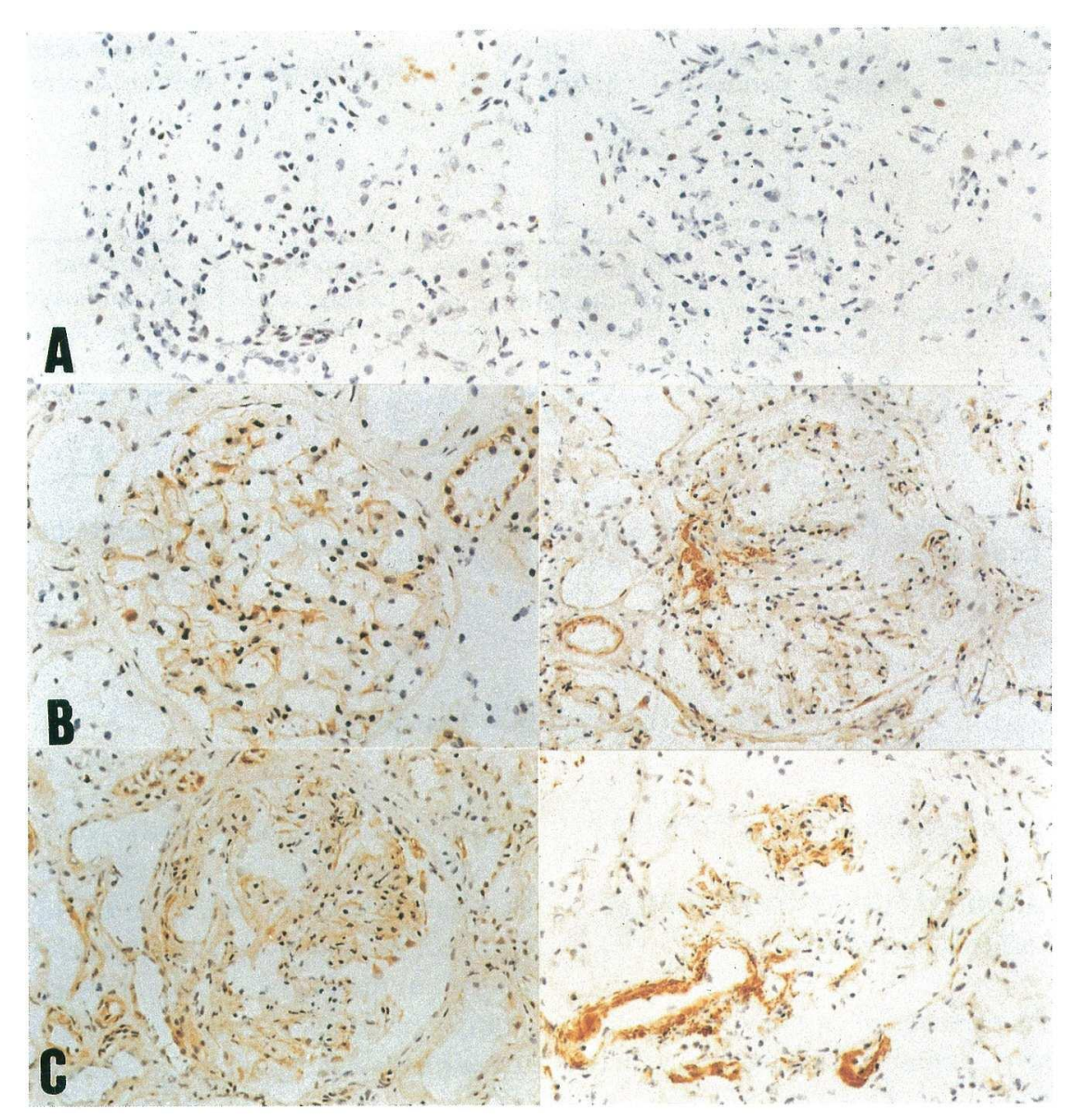

Figure 2. Immunohistochemical detection of pentosidine (left panel) and HNEprotein adduct (right) in normal (A) and diabetic renal tissues ( $B$ and $C$ ). The pentosidine and HNE-protein product antibodies did not stain the glomeruli in normal subjects. By contrast, both pentosidine and HNE-protein product were stained positive in the expanded mesangial area $(B)$ and in nodular lesions $(C)(\times 200)$.

These data suggest a broad derangement in non-enzymatic biochemistry in diabetic glomerular lesions, and implicate an increased local oxidative stress and carbonyl modification of proteins in diabetic glomerular tissue damage.

\section{Role of Carbonyl Stress in Diabetic Nephropathy}

The pathological significance of carbonyl stress in diabetic glomerular lesions is an issue of particular interest. As already described, the final protein adducts resulting from carbonyl stress, such as AGE modified proteins, stimulate a variety of cellular responses including glomerular mesangial cells. Furthermore, carbonyl stress may also have direct biological effects.

Reactive carbonyl compounds and residual carbonyl groups on AGE-modified proteins react covalently with matrix tissue proteins and alter their structures and functions. Or, they react with cell surface proteins and stimulate cellular responses by cross-linking cell surface proteins $(57,58)$. We recently demonstrated an increased intracellular protein-tyrosine phosphorylation in murine thymocytes and fibroblasts by interaction with carbonyl compounds, such as glyoxal and MDA (59). This increased protein-tyrosine phosphorylation may be attributed to the cross-linking of cell surface proteins and the subsequent activation of some protein tyrosine kinase, such as c-Src (59). The protein-tyrosine phosphorylation by interaction with carbonyl compounds is completely inhibited by pretreatment with 2-isopropylidenehydrazono-4-oxo-thiazolidin-5-ylacetanilide (OPB-9195), an inhibitor of carbonyl-amine reactions $(50,59)$. Numerous intracellular proteins are also phosphorylated on tyrosine residues in primary cultured human and rat mesangial cells exposed to carbonyl compounds (60).

Acknowledgements: The authors express their special thanks to Professors Kiyoshi Kurokawa and Hideto Sakai for their encouragement and invaluable suggestions during the studies. This study was supported by grants from Research for the Future Program of the Japan Society for the Promotion of Science (96L00303) and from the Ministry of Health and Welfare on Research 


\section{Carbonyl Stress in Diabetic Nephropathy}

on Health Services (H10-079)

\section{References}

1) Brenner BM, Anderson S. Glomerular function in diabetes mellitus. Adv Nephrol Necker Hosp 19: 135-144, 1990.

2) Barnett PA, Gonzalez RG, Chylack LT Jr, Cheng HM. The effect of oxidation on sorbitol pathway kinetics. Diabetes 35: 426-432, 1986.

3) Greene DA, Lattimer SA, Sima AA. Sorbitol, phosphoinositides, and sodium-potassium-ATPase in the pathogenesis of diabetic complications. N Engl J Med 316: 599-606, 1987.

4) Inoguchi T, Battan R, Handler E, Sportsman JR, Heath W, King GL. Preferential elevation of protein kinase $\mathrm{C}$ isoform beta II and diacylglycerol levels in the aorta and heart of diabetic rats: differential reversibility to glycemic control by islet cell transplantation. Proc Natl Acad Sci USA 89: 11059-11063, 1992.

5) Lee TS, Saltsman KA, Ohashi H, King GL. Activation of protein kinase $\mathrm{C}$ by elevation of glucose concentration: proposal for a mechanism in the development of diabetic vascular complications. Proc Natl Acad Sci USA 86: 5141-5145, 1989 (published erratum appears in Proc Natl Acad Sci USA 88: 9907, 1991).

6) Yagame M, Eguchi K, Suzuki D, et al. Fibrinolysis in patients with diabetic nephropathy determined by plasmin-alpha2 plasmin inhibitor complexes in plasma. J Diabetic Complications 4: 175-178, 1990.

7) Krolewski AS, Doria A, Magre J, Warram JH, Housman D. Molecular genetic approaches to the identification of genes involved in the development of nephropathy in insulin-dependent diabetes mellitus. J Am Soc Nephrol 3 (Suppl): S9-17, 1992.

8) Suzuki D, Miyazaki M, Naka R, et al. In situ hybridization of interleukin 6 in diabetic nephropathy. Diabetes 44: 1233-1238, 1995.

9) Sakai H, Naka R, Suzuki D, et al. In situ hybridization analysis of TGFbeta in glomeruli from patients with IgA nephropathy. Contrib Nephrol 111: 107-115, 1995.

10) Abboud HE. Growth factors and diabetic nephropathy: an overview. Kidney Int Suppl 60: S3-S6, 1997.

11) Abboud HE. Growth factors in glomerulonephritis. Kidney Int 43: 252267, 1993 (clinical conference).

12) Pfeiffer A, Schatz H. Diabetic microvascular complications and growth factors. Exp Clin Endocrinol Diabetes 103: 7-14, 1995.

13) Suzuki D, Miyazaki M, Jinde K, et al. In situ hybridization studies of matrix metalloproteinase-3, tissue inhibitor of metalloproteinase-1 and type IV collagen in diabetic nephropathy. Kidney Int 52: 111-119, 1997.

14) Suzuki D. Metalloproteinases in the Pathogenesis of Diabetic Nephropathy. Nephron 80: 125-133, 1998.

15) The Diabetes Control and Complications (DCCT) Research Group. Effect of intensive therapy on the development and progression of diabetic nephropathy in the Diabetic Control and Complications Trial. Kidney Int 47: 1703-1720, 1995.

16) Bangstad HJ, Osterby R, Dahl-Jorgensen K, Berg KJ, Hartmann A, Hanssen KF. Improvement of blood glucose control in IDDM patients retards the progression of morphological changes in early diabetic nephropathy. Diabetologia 37: 483-490, 1994.

17) Dyer DG, Dunn JA, Thorpe SR, et al. Accumulation of Maillard reaction products in skin collagen in diabetes and aging. J Clin Invest 91: 24632469, 1993.

18) Brownlee M, Cerami A, Vlassara $\mathrm{H}$. Advanced glycosylation end products in tissue and the biochemical basis of diabetic complications. N Engl J Med 318: 1315-1321, 1988.

19) Suzuki D, Yagame M, Naka R, et al. Immunohistochemical staining of renal biopsy samples in patients with diabetic nephropathy in non-insulin dependent diabetes mellitus using monoclonal antibody to advanced glycation end products. Nephrology 1: 199-205, 1995.

20) Suzuki D, Yagame M, Jinde K, et al. Immunofluorescence staining of renal biopsy samples in patients with diabetic nephropathy in non-insulin-dependent diabetes mellitus using monoclonal antibody to reduced glycated lysine. J Diabetes Complications 10: 314-319, 1996.
21) Ahmed MU, Thorpe SR, Baynes JW. Identification of $N^{\varepsilon_{-}}$ carboxymethyllysine as a degradation product of fructoselysine in glycated protein. J Biol Chem 261: 4889-4894, 1986.

22) Sell DR, Monnier VM. Structure elucidation of a senescence cross-link from human extracellular matrix. Implication of pentoses in the aging process. J Biol Chem 264: 21597-21602, 1989.

23) Njoroge FG, Sayre LM, Monnier VM. Detection of D-glucose-derived pyrrole compounds during Maillard reaction under physiological conditions. Carbohydr Res 167: 211-220, 1987.

24) Sugiyama S, Miyata T, Ueda $Y$, et al. Plasma levels of pentosidine in diabetic patients: an advanced glycation end product. J Am Soc Nephrol 9: 1681-1688, 1998.

25) Sell DR, Lapolla A, Odetti P, Fogarty J, Monnier VM. Pentosidine formation in skin correlates with severity of complication in individuals with long-standing IDDM. Diabetes 41: 1286-1292, 1992.

26) McCance DR, Dyer DG, Dunn JA, et al. Maillard reaction products and their relation to complications in insulin-dependent diabetes mellitus. J Clin Invest 91: 2470-2478, 1993.

27) Horie $K$, Miyata $T$, Maeda $K$, et al. Immunohistochemical colocalization of glycoxidation products and lipid peroxidation products in diabetic renal glomerular lesions. Implication for glycoxidative stress in the pathogenesis of diabetic nephropathy. J Clin Invest 100: 2995-3004, 1997.

28) Beisswenger PJ, Moore LL, Brinck-Johnsen T. Curphey TJ. Increased collagen-linked pentosidine levels and advanced glycosylation end products in early diabetic nephropathy. J Clin Invest 92: 212-217, 1993.

29) Cohen MP, Ziyadeh FN. Amadori glucose adducts modulate mesangial cell growth and collagen gene expression. Kidney Int 45: 475-484, 1994.

30) Cohen MP, Surma ML, Wu VY. In vivo biosynthesis and turnover of glomerular basement membrane in diabetic rats. Am J Physiol 242: F385F389, 1982.

31) Doi T, Vlassara H, Kirstein M, Yamada Y, Striker GE, Striker LJ. Receptor-specific increase in extracellular matrix production in mouse mesangial cells by advanced glycosylation end products is mediated via plateletderived growth factor. Proc Natl Acad Sci USA 89: 2873-2877, 1992.

32) Yang CW, Vlassara H, Peten EP, He CJ, Striker GE, Striker LJ. Advanced glycation end products up-regulate gene expression found in diabetic glomerular disease. Proc Natl Acad Sci USA 91: 9436-9440, 1994.

33) Vlassara H, Brownlee M, Manogue KR, Dinarello CA, Pasagian A. Cachectin/TNF and IL-1 induced by glucose-modified proteins: role in normal tissue remodeling. Science 240: 1546-1548, 1998.

34) Miyata $T$, Inagi $R$, Iida $Y$, et al. Involvement of beta 2 -microglobulin modified with advanced glycation end products in the pathogenesis of hemodialysis-associated amyloidosis: Induction of human monocyte chemotaxis and macrophage secretion of tumor necrosis factor-alpha and interleukin-1. J Clin Invest 93: 521-528, 1994.

35) Miyata T, Iida Y, Ueda Y, et al. Monocyte/macrophage response to beta 2-microglobulin modified with advanced glycation end products. Kidney Int 49: 538-550, 1996.

36) Neeper M, Schmidt AM, Brett J, et al. Cloning and expression of a cell surface receptor for advanced glycosylation end products of proteins. $\mathbf{J}$ Biol Chem 267: 14998-15004, 1992.

37) Miyata $T$, Hori $O$, Zhang J, et al. The receptor for advanced glycation end products (RAGE) is a central mediator of the interaction of AGEbeta2microglobulin with human mononuclear phagocytes via an oxidantsensitive pathway. Implications for the pathogenesis of dialysis-ralated amyloidosis. J Clin Invest 98: 1088-1094, 1996.

38) Skolnik EY, Yang Z, Makita Z, Radoff S, Kirstein M, Vlassara H. Human and rat mesangial cell receptors for glucose-modified proteins: potential role in kidney tissue remodelling and diabetic nephropathy. J Exp Med 174: 931-939, 1991.

39) Brett J, Schmidt AM, Yan SD, et al. Survey of the distribution of a newly characterized receptor for advanced glycation end products in tissues. Am J Pathol 143: 1699-1712, 1993.

40) Wells-Knecht KJ, Zyzak DV, Litchfield JE, Thorpe SR, Baynes JW. Mechanism of autoxidative glycosylation: identification of glyoxal and arabinose as intermediates in the autoxidative modification of proteins by glucose. Biochemistry 34: 3702-3709, 1995. 


\section{SUZUKI and MIYATA}

41) Ahmed MU, Frye EB, Degenhardt TP, Thorpe SR, Baynes JW. $N^{\varepsilon}$-(carboxymethyl) lysine, a product of the chemical modification of proteins by methylglyoxal, increases with age in human lens proteins. Biochem $\mathbf{J}$ 324: 565-570, 1997.

42) Glomb MA, Monnier VM. Mechanism of protein modification by glyoxal and glycolaldehyde, reactive intermediates of the Maillard reaction. J Biol Chem 270: 10017-10026, 1995.

43) Dunn JA, Ahmed MU, Murtiashaw MH, et al. Reaction of ascorbate with lysine and protein under autoxidizing conditions: formation of $N^{\varepsilon}$-(carboxymethyl) lysine by reaction between lysine and products of autoxidation of ascorbate. Biochemistry 29: 10964-10970, 1990.

44) Miyata $T$, Wada $Y$, Cai $Z$, et al. Implication of an increased oxidative stress in the formation of advanced glycation end products in patients with end-stage renal failure. Kidney Int 51: 1170-1181, 1997.

45) Fu MX, Requena JR, Jenkins AJ, Lyons TJ, Baynes JW, Thorpe SR. The advanced glycation end products, $N^{\varepsilon}$-(carboxymethyl) lysine, is a product of both lipid peroxidation and glycoxidation reactions. J Biol Chem 271: 9982-9986, 1996

46) Esterbauer H, Schuer RJ, Zollner H. Chemistry and biochemistry of 4hydroxynonenal, malonaldehyde and related aldehyde. Free Radic Biol Med 11: 81-128, 1991.

47) Uchida K, Kanematsu M, Sakai K, et al. Protein-bound acrolein: potential markers for oxidative stress. Proc Natl Acad Sci USA 95: 4882-4887, 1998.

48) Anderson MM, Hazen SL, Hsu FF, Heinecke JW. Human neutrophils employ the myeloperoxidase-hydrogen peroxide-chloride system to convert hydroxy-amino acids into glycolaldehyde, 2-hydroxypropanal, and acrolein. A mechanism for the generation of highly reactive alpha-hydroxy and alpha, beta-unsaturated aldehydes by phagocytes at sites of inflammation. J Clin Invest 99: 424-432, 1997.

49) Baynes JW. Role of oxidative stress in development of complications in diabetes. Diabetes 40: 405-412, 1991.

50) Miyata T, van Ypersele de Strihou C, Kurokawa K, Baynes JW. Alterations in non-enzymatic biochemistry in uremia: origin and significance of "carbonyl stress" in long-term uremic complications. Kidney Int $\mathbf{5 5}$ 389-399, 1999.

51) Suzuki D, Miyata T, Saotome N, et al. Immunohistochemical evidence for an increased oxidative stress and carbonyl modification of proteins in diabetic glomerular lesion. J Am Soc Nephrol 10: 822-832, 1999.

52) Schmitz A, Gundersen HJ, Osterby R. Glomerular morphology by light microscopy in non-insulin-dependent diabetes mellitus. Lack of glomerular hypertrophy. Diabetes 37: 38-43, 1988.

53) Hayashi $H$, Karasawa $R$, Inn $H$, et al. An electron microscopic study of glomeruli in Japanese patients with non-insulin dependent diabetes mellitus. Kidney Int 41: 749-757, 1992.

54) Mauer SM, Steffes MW, Ellis EN, Sutherland DE, Brown DM, Goetz FC. Structural-functional relationships in diabetic nephropathy. J Clin Invest 74: 1143-1155, 1984.

55) Steffes MW, Osterby R, Chavers B, Mauer SM. Mesangial expansion as a central mechanism for loss of kidney function in diabetic patients. Diabetes 38: 1077-1081, 1989.

56) Steffes MW, Bilous RW, Sutherland DE, Mauer SM. Cell and matrix components of the glomerular mesangium in type I diabetes. Diabetes 41 : 679-684, 1992.

57) Rhodes J. Covalent chemical events in immune induction: fundamental and therapeutic aspects. Immunol Today 9: 436-441, 1996.

58) Leonarduzzi G, Scavazza A, Biasi F, et al. The lipid peroxidation end product 4-hydroxy-2, 3-nonenal up-regulates transforming growth factor betal expression in the macrophage lineage: a link between oxidative injury and fibrosclerosis. FASEB J 11: 851-857, 1997.

59) Ahkand A, Kato M, Suzuki H, et al. Carbonyl stress modifies cell surface protein for activating protein-tyrosine kinase p60c-Src. J Cell Biochem 72: 1-7, 1999.

60) Yasuda Y, Miyata T, Ahkand A, et al. Carbonyl stress in diabetic glomerular lesions modifies mesangial cell surface protein for activating the intracellular protein tyrosine phosphorylation. J Am Soc Nephrol 9: 3296A (Abstract), 1998. 